\title{
Teachers' knowledge of disability and inclusion: keys to educational inclusion
}

\author{
Medina-García, Marta ${ }^{1}$, Higueras-Rodríguez, María Lina ${ }^{2,}{ }^{3}$ Doña-Toledo, Luis \\ ${ }^{1}$ University of Jaén, Spain \\ ${ }^{2}$ University of Almería, Spain \\ 3University of Granada
}

\begin{abstract}
.
Inclusive education refers to the right of all persons to education, ensuring the presence, participation and progress of all students. However, at present, this is a dual and controversial issue, as it appears among the strategies and objectives planned at international and European level, but its application and real development is still far from being a right with guarantees. The objectives that we propose with this work are: to review the state of the art on the measure of inclusion in the teaching profession and to develop a causal model that allows us to know which factors are significant in achieving true inclusion. The method used is a multivariate analysis through exploratory factor analysis and a multiple linear regression model. The sample is made up of 133 teachers from the Andalusian territory. The results show that knowledge about disability is not significant to achieve an inclusive system, but that the decisive factor is knowledge about inclusion. Also positive are the measures to improve the teaching staff and the integration measures as a previous step to inclusion. The conclusions of this work provide education managers and teachers with information on those aspects which need to be improved in order to achieve one of the objectives of sustainable development, namely, inclusive education.
\end{abstract}

Keywords: disability, inclusion, teachers, linear regression, factor analysis

\section{Introduction}

One of the biggest challenges facing the education system today is to ensure the educational inclusion of all children. This is set out by UNESCO (2015) in its Sustainable Development Agenda, specifically in goal 4 (ODS 4) and is confirmed by authors such as Ainscow and Sandill, (2010).

In this sense, inclusive education becomes an essential element to guarantee the right of all people to a quality education (Dávila and Naya, 2011). According to Calvo and Verdugo (2012), we could define inclusive education as education for all, and in this sense, differences are understood as enrichment, as an aspect that unites all people. As Booth \& Ainscow (2015) 


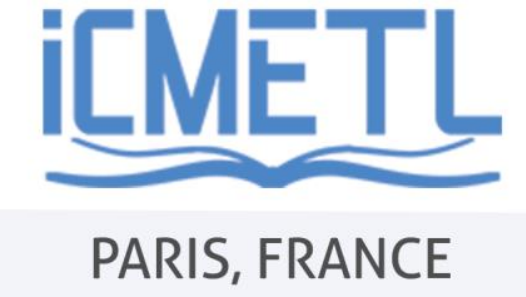

20-22 NOVEMBER, 2020

indicate, we cannot remain with a reduced vision of what this process means by identifying it only with the concern of certain students at risk of exclusion.

In short, we are referring to a right recognised by the international community. As an example, the United Nations High Commissioner for Human Rights (OHCHR, 2013) recognizes inclusive education as the most appropriate way for States to ensure universality and non-discrimination in the right to education. As Opertti and Guillinta (2015) point out, the right to education is set out in numerous international documents of varying legal nature, from whose analysis and reflection the recognition that the right to inclusive education is implicit (Medina, 2017). However, this right is still far from being the "norm" in actual implementation.

The achievement of this objective is a process that requires the participation of many social agents (Calvo and Verdugo, 2012) and there is no doubt that teachers are an essential part of its achievement. Teachers are seen as key elements in implementing inclusive education (De Boer et al., 2011). For this reason, a fundamental aspect is the knowledge that they have in terms of inclusive education and which aspects are significant for the implementation of this in the educational reality.

\section{Methodology}

For the development of this study we have taken as our population the teachers of Compulsory Secondary Education and therapeutic pedagogy professionals in Andalusia. To obtain the sample, we used a non-probabilistic snowball sample. The field work was carried out during January 2016.

In this way, we found a population of about 9,000 teachers in the target region of analysis from which we finally obtained a sample of 133 subjects with a sampling error of $3.7 \%$ with a confidence percentage of $95 \%$. The characteristics of the sample are detailed below, where it stands out that $60 \%$ of the respondents claimed to have medium/high knowledge about the field of disability, while $20.2 \%$ claimed to know hardly anything about this field. On the other hand, almost $65 \%$ of the sample is made up of women and almost $65 \%$ of the sample are professionals who work in public education centres.

Table 1. Characterization of the sample.

\begin{tabular}{|c|l|l|l|}
\hline \multirow{2}{*}{ Variable } & Category & \multicolumn{2}{|c|}{ Sample } \\
\cline { 3 - 4 } & & $\mathrm{N}$ & $\%$ \\
\hline \multirow{2}{*}{ Gender } & Men & 47 & 35,3 \\
\cline { 3 - 5 } & Women & 89 & 64,7 \\
\hline \multirow{2}{*}{$\begin{array}{c}\text { Has knowledge about } \\
\text { disability }\end{array}$} & Yes & 86 & 64,7 \\
\cline { 2 - 4 } & No & 27 & 20,2 \\
\cline { 2 - 4 } & NS/NC & 20 & 15,0 \\
\hline
\end{tabular}


20-22 NOVEMBER, 2020

\begin{tabular}{|c|c|c|c|}
\hline \multirow{6}{*}{$\begin{array}{l}\text { Years of teaching experience } \\
\text { (years) }\end{array}$} & $1-5$ & 28 & 21,1 \\
\hline & $6-10$ & 32 & 24,1 \\
\hline & $11-15$ & 18 & 13,5 \\
\hline & $16-20$ & 9 & 6,8 \\
\hline & Más de 20 & 45 & 33,8 \\
\hline & $\mathrm{NS} / \mathrm{NC}$ & 1 & 0,8 \\
\hline \multirow[t]{4}{*}{ Type of centre } & Public & 86 & 64,7 \\
\hline & Private & 16 & 12,0 \\
\hline & Concerted & 24 & 18,0 \\
\hline & $\mathrm{NS} / \mathrm{NC}$ & 7 & 5,3 \\
\hline \multirow[t]{5}{*}{ Age } & $21-30$ & 23 & 17,3 \\
\hline & $31-40$ & 39 & 29,3 \\
\hline & $41-50$ & 37 & 27,8 \\
\hline & $51-60$ & 30 & 22,6 \\
\hline & $\mathrm{NS} / \mathrm{NC}$ & 4 & 3,0 \\
\hline
\end{tabular}

To carry out our study we used a questionnaire as a data collection technique with a total of 53 items. This was a self-administered on-line questionnaire. The questionnaire consisted of two parts: (1) classification of the respondents and socio-demographic variables (sex, age, centre, etc.) as well as a total of 45 Likert-type scale questions (from 1 to 5) about three fundamental aspects: knowledge about disability, consideration and effectiveness of diversity measures, opinion and information about inclusion.

A pre-test was carried out during the year 2015. The results of the survey were analysed by 16 educators with more than 20 years of experience working in public centres. With the results found, the correct elaboration and understanding was checked again, correcting the errors detected. In addition, the content validity and reliability were checked with an Alpha de Cronbrach value of more than 0.7 (0.803).

As for the measures of the variables, as mentioned above, no scales for measuring the inclusion of education systems have been located recently, which is an important novelty of this work. Some research such as Wilczenski (1995), Sharma, Forlin and Loreman, T. (2008) or Humphrey and Symes (2013) measured teachers' attitudes towards students with disabilities, an objective which differs from our aim of developing a broad vision of all the components of inclusion. However, we have incorporated the relevant variables, opinion items and attitudes located during the literature review and the articles cited 


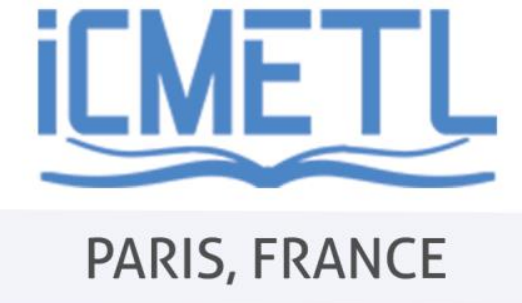

20-22 NOVEMBER, 2020

\section{Results}

\subsection{Underlying dimensions of inclusion in the educational context}

In order to know and compare how the dimensions included in the questionnaire are structured, an exploratory factorial analysis was carried out to understand how the items related to educational inclusion behave (45 total). The analysis offered adequate values of KMO (0.71) and Barlett's sphericity test $(\mathrm{p}=0.00)$ favourable for the analysis. The communities, that is to say, the representation of the different items of the questionnaire within the factorial analysis exceeded in all cases the minimum value of 0.5 , with the exception of the item referred to the "specific classroom schooling modality" (0.459). However, it was decided to maintain this value since it is very close to 0.5 and would not affect the factorial solution given the very good results achieved in both the goodness of fit and communality analyses.

A total number of ten factors was selected given the criterion of choosing self values higher than 1 and according to the Kaiser test. These factors represent $62.8 \%$ of the total variance explained. A rotation phase was then carried out using the Varimax procedure to find out the structure of the seven factors. This rotation was used because it is an orthogonal method and also because it is one of the most widely used approaches, as highlighted by Luque (2012). The results do not vary when other orthogonal rotation methods are used, such as Quartimax or Equimax. Table 2 provides the 10 underlying factors of inclusion that make up the scale you call CESI (components of an inclusive education system). All dimensions reached a Cronbrach's Alpha value above 0.7 which confirms the reliability of the dimensions achieved.

Table 2. Factorial solution scale inclusion

\begin{tabular}{|l|l|c|}
\hline factor & denomination & $\begin{array}{c}\text { variance } \\
\text { explained(\%) }\end{array}$ \\
\hline 1 & diversity awareness measures & 12,97 \\
\hline 2 & measures for the integration of pupils & 6,90 \\
\hline 3 & adequacy of the education system with respect to inclusion & 6,70 \\
\hline 4 & knowledge about disability & 6,00 \\
\hline 5 & knowledge about inclusion & 5,79 \\
\hline 6 & benefits of equality & 5,78 \\
\hline 7 & measures to promote equality & 5,05 \\
\hline 8 & inclusion of students & 4,86 \\
\hline 9 & difficulties arising from the teaching staff & 4,84 \\
\hline 10 & special educational needs & 3,95 \\
\hline
\end{tabular}




\section{$2^{\text {nd }}$ International Conference on Modern Research in EDUCATION, TEACHING AND LEARNING}

\section{ICMETL \\ PARIS, FRANCE}

\section{0-22 NOVEMBER, 2020}

This factorial solution offers great value by being able to build and propose a scale of measurement about the inclusion of the educational system from the perception of the teachers. An inclusive education system is comprised of dimensions such as measures of care or integration, teachers and their performance, as well as knowledge about different aspects of inclusion.

The factors obtained in the previous section allow us the possibility of carrying out models or causal relationships that explain different aspects related to inclusion. This will allow us to know in a parsimonious and clear way which are those dimensions that correlate more strongly with certain key points of the education system. A multiple regression causal model is carried out, which in our case will be done using the linear regression method.

The main objective is to find out which aspects shape and explain the perception of an inclusive education system. To this end, four of the dimensions obtained in the factorial solution have been included. The factors included are all those related to knowledge about disability, teaching staff and measures for the integration of students. The rest of the factors have not been considered since they are consequences of the inclusion itself, that is to say, they do not form an inclusive education system, but are a cause of it.

Thus, the model which explains the inclusive system would be determined in this way:

\section{INCLUSIVE SYSTEM= $\beta 1+\beta 2$ Integration measures $+\beta 3$ Knowledge about disability+ $\beta 4$ Knowledge about inclusion $+\beta 5$ Teachers + Ui}

The model is significant as a whole through the ANOVA test $(\mathrm{P}=0.000)$ and in this case the r-square obtained is $30 \%$ so it has a high explanatory capacity.

Observing the previous table in the p-value column, it is indicated that, with a $95 \%$ confidence level, where it is possible to check which values are significant in our model and which are not. In our case, all variables are significant at 5\%, except in the case of integration measures that are quasi-significant (at 10\%).

From the "Beta" column we can deduce the order of importance of the explanatory or independent variables. In this way, the explanatory variable that acquires less weight is knowledge of disability (0.161) while that which explains most is knowledge of inclusion (0.318).

In addition, in the column of parameters $\mathrm{B}$, the coefficients of variation that are produced in the dependent variable in the face of the unitary variation of some of the variables can be observed, assuming that the rest of the variables remain constant. Thus, according to the results, any increase in all the explanatory variables would increase inclusion. For example, on improving knowledge about disability by one unit, it would increase by 0.179 . Knowledge about inclusion is what would cause a greater increase (0.354). All the relationships of the independent variables with the dependent one are positive, so that any improvement in any of the significant aspects on which inclusion depends would increase the latter.

In a detailed analysis of each of the cause variables included in the model 


\section{0-22 NOVEMBER, 2020}

- Integration measures is the second most important aspect in shaping an inclusive education system in a meaningful way $(\mathrm{p}=0.000)$. Improving any aspect of these measures would significantly increase inclusion in the educational environment (Beta=0.348).

- Knowledge about disability also has a positive and significant effect although in this case with a $10 \%$ confidence level $(\mathrm{p}=0.059)$. This is the last factor in order of importance.

- As might be expected, knowledge about inclusion is the main element in shaping an inclusive education system. It reaches a beta value of 0.354 . Significantly, improving the information and knowledge of all agents in the social and educational system would allow for higher levels of inclusion.

- Finally, the third most important aspect for achieving an inclusive education system is the teaching staff itself $(p=0.001)$. It is determined that improving their shortcomings, lack of preparation or their possible collaboration in achieving equal opportunities has a positive impact.

Table 3. Results of the inclusive system model

\begin{tabular}{|c|c|c|c|c|c|}
\hline \multirow[t]{2}{*}{ Model } & \multicolumn{2}{|c|}{$\begin{array}{l}\text { non-standardised } \\
\text { coefficients }\end{array}$} & \multirow{2}{*}{$\begin{array}{c}\begin{array}{c}\text { standardised } \\
\text { coefficients }\end{array} \\
\text { Beta }\end{array}$} & \multirow[t]{2}{*}{$\mathrm{t}$} & \multirow[t]{2}{*}{ Sig } \\
\hline & $\mathrm{B}$ & $\begin{array}{l}\text { Desv. } \\
\text { Error }\end{array}$ & & & \\
\hline (Constant) & 2,923 & ,093 & & $434^{31,}$ & $0^{, 00}$ \\
\hline $\begin{array}{l}\text { knowledge } \quad \text { about } \\
\text { inclusion }\end{array}$ &, 354 & ,093 & ,318 & $86^{3,7}$ & $0^{, 00}$ \\
\hline $\begin{array}{l}\text { knowledge } \quad \text { about } \\
\text { disability }\end{array}$ & , 179 & ,093 &, 161 & $12^{1,9}$ & $9^{, 05}$ \\
\hline $\begin{array}{l}\text { measures for the } \\
\text { integration of pupils }\end{array}$ & ,348 & ,093 &, 312 & $19^{3,7}$ & $0^{, 00}$ \\
\hline teacher improvement & ,307 & ,093 &, 276 & $90^{3,2}$ & $1^{, 00}$ \\
\hline
\end{tabular}

Finally, the solution of the causal model obtained is offered below:

INCLUSIVE SYSTEM =2,923 + 0,348 Integration measures $+0,179$ Knowledge about disability $+0,354$ Knowledge about inclusion + 0,307Teachers $+0,093$ 


\section{$2^{\text {nd }}$ International Conference on Modern Research in EDUCATION, TEACHING AND LEARNING}

\section{ICMETL \\ PARIS, FRANCE}

\section{0-22 NOVEMBER, 2020}

\section{Discussion}

In view of the results obtained, it is essential to know and contrast our data with what has been set out in previous work and research on the subject.

With regard to teachers' attitudes, the results of Horne and Timmons' study (2009) indicate that the main concerns expressed by teachers were having time to plan their work, achieving the needs of all students and having sufficient continuous professional development to effectively meet the needs present in all students. Most teachers show a neutral or negative attitude towards educational inclusion as reflected in the research findings of Boer, Pijl \& Minnaert (2011). The availability of resources is shown to be a concern in achieving inclusion (Sharma and Desai, 2002).

Similarly, knowledge and training on the subject becomes a key aspect as reflected in our data, as the current confusion among teachers when differentiating terms such as inclusion and integration is another aspect to highlight (Unianu, 2012). In this sense, the findings of Vaz et al. (2014), which demonstrate the importance of teachers' knowledge to improve inclusion, are particularly relevant. In terms of knowledge, the study by Vanderpuye, Obosu and Nishimuko (2018) shows that the obvious needs of teachers are focused on information about disability and training in the adaptation of materials. This is in line with the research findings of Moreno-Rodríguez, López, Carnicero, Garrote, and Sánchez (2017); Barrio, Miller, Ojeme, and Tamakloe (2019) which reveal the need for more education and training on this subject.

In relation to the knowledge of disability and inclusion of teachers and professors on which our work places special emphasis, the results of Kamenopoulou, \& Dukpa, (2018) coincide in this respect as they expose these aspects as deficient and contrary to inclusion, showing the lack of knowledge and teacher training as an obstacle to the implementation of educational inclusion.

In short, teachers must receive training, education and information on all aspects of educational inclusion. However, the literature does not find studies that indicate what aspects should be established and developed to guarantee inclusive education from the point of view of teachers, that is, what their opinion or assessment is of the components that currently make up the system (Medina and Doña, 2020).

\section{Conclusion}

In order to achieve the implementation of inclusive education we need to know, among other things, those aspects that really give it meaning or are really significant for its implementation.

For this reason, the objectives that we propose to address with this work are aimed, on the one hand, at reviewing the factors that measure inclusion in teaching staff. And, on the other hand, to develop a causal model that allows us to know which factors are significant for achieving true inclusion. 


\section{0-22 NOVEMBER, 2020}

So, once the study has been carried out, we can conclude the following. We have managed to identify 10 relevant factors of inclusion, such as measures of attention to diversity, teachers and their performance, as well as knowledge about different aspects of inclusion, with which we can propose a scale of measurement about the inclusion of the education system from the perception of teachers.

Furthermore, in order to find out which aspects make up and explain the perception of an inclusive education system, the results show us the following. Firstly, knowledge about inclusion, which is the main element when it comes to setting up an inclusive education system. This is followed by integration measures and the figure of the teachers themselves. And finally, knowledge about disability.

These results have an important transference to practice as they offer relevant information on the basic aspects for the implementation of the inclusion process, becoming reference elements both for educational centres and for educational managers, as they propose the appropriate guidelines to influence decisions and elements of organization and management which are essential for tackling educational inclusion.

\section{Acknowledgment}

This paper is an output of the science project...

\section{References}

[1] Barrio, BL.; Miller, D.; Ojeme, C; Tamakloe, D. Conocimiento de maestros y padres sobre discapacidades e inclusión en Nigeria. J. Inter. Spec. Needs Educ., 2019, 22 (1), 14 24.

[2] Booth, T., \& Ainscow, M. (2015). Guía para la educación inclusiva. Desarrollando el aprendizaje y la participación en los centros escolares. FUHEM, OEI.

[3] Calvo Álvarez, M. I., \& Verdugo Alonso, M. Á. (2012). Educación inclusiva, ¿una realidad o un ideal?. Edetania, (41), 17-30.

[4] Cook, B. G., Cameron, D. L., \& Tankersley, M. (2007). Inclusive teachers' attitudinal ratings of their students with disabilities. The Journal of Special Education, 40, 230-238.

[5] Dávila, P., \& Naya, L. M. (2013). Derechos de la infancia y educación inclusiva en América Latina. Ediciones Granica.

[6] De Boer, A., Pijl, S. J., \& Minnaert, A. (2011). Regular primary schoolteachers' attitudes towards inclusive education: A review of the literature. International journal of inclusive education, 15(3), 331-353.

[7] Hodkinson, A. (2009). Pre-service teacher training and special educational needs in England 1970-2008: Is government learning the lessons of the past or is it experiencing a groundhog day? European Journal of Special Needs Education, 24, 277-289. 


\section{ICMETL \\ PARIS, FRANCE}

\section{0-22 NOVEMBER, 2020}

[8] Horne, P. E. \& Timmons, V. (2009). Making it work: Teachers' perspectives on inclusion. International Journal of Inclusive Education, 13, 273-278.

[9] Kamenopoulou, L.; Dukpa, D. Karma and human rights: Bhutanese teachers' perspectives on inclusion and disability. Inter. J. Incl. Educ., 2018, 22(3), 323-338.

[10] Medina García, M.; Doña-Toledo, L. The Elements of an Inclusive Educational System as Seen from the Perspective of Teachers. Psic. Esc. Educ., 2020. In press.

[11] Medina, M. (2017). La educación inclusiva como mecanismo de garantía de la igualdad de oportunidades y no discriminación de las personas con discapacidad. Una propuesta de estrategias pedagógicas inclusivas. (Tesis Doctoral). Universidad de Jaén, España.

[12] Moreno-Rodríguez, R.; López, JL.; Carnicero, JD.; Garrote, I; Sánchez, S. Percepción de los docentes sobre la inclusión de estudiantes con discapacidades en el aula de educación regular en Ecuador. Rev. Est. Educ. Form., 2017, 5 (9), 45-53

[13] Opertti, R., \& Guillinta, Y. (2015). La educación inclusiva: 48 ${ }^{\mathrm{a}}$ Conferencia Internacional de educación. Páginas de Educación, 2(1), 137-148.

[14] Sharma, U., \& Desai, I. (2002). Measuring concerns about integrated education in India. Asia and Pacific Journal on Disability, 5(1), 2-14.

[15] UNESCO. Global Monitoring Report on Education, 2015. Available online: es.unesco.org/gem-report/

[16] Unianu, E. M. (2012). Teachers' attitudes towards inclusive education. ProcediaSocial and Behavioral Sciences, 33, 900-904.

[17] Vanderpuye, I.; Obosu, GK.; Nishimuko, M. Sostenibilidad de la educación inclusiva en Ghana: actitud de los docentes, percepción de los recursos necesarios y percepción del posible impacto en los alumnos. Rev. Inter. Educ. Incl., 2018, 1-13.

Vaz, S., Wilson, N., Falkmer, M., Sim, A., Scott, M., Cordier, R., \& Falkmer, T. (2014). Factors associated with primary school teachers' attitudes towards the inclusion of students with disabilities. PloS one, 10(8), e0137002. 